\title{
Pengaruh Kompetensi Auditor, Kompleksitas Tugas, Skeptisme Professional terhadap Kualitas Audit dengan Due Professional Care sebagai Variabel Moderating pada Kantor Akuntan Publik di Medan
}

\author{
Sophia Tanady ${ }^{1 *}$, Jessy Meilavia ${ }^{1}$, Wilsa Road Betterment Sitepu ${ }^{1}$ \\ ${ }^{1}$ Fakultas Ekonomi, Universitas Prima \\ Jl. Sekip, Kec, Medan Petisah, Kota Medan, Sumatera utara \\ E-mail: *1Phiapma9909@gmail.com, ${ }^{1}$ wilsa_better_sitepu@yahoo.com \\ Received: Februari 2021; Accepted: Mei 2021; Published: Juni 2021
}

\begin{abstract}
In this modern era, the services of an auditor are very much needed by government agencies and private agencies because the results of the decisions made by auditors can reflect the transparency of an organization. An auditor must have an attitude of competence and good skepticism so that when assessing an organization, no mistakes occur. The attitude of complexity is also an attitude that must be possessed by an auditor where an auditor must be able to know what difficulties or obstacles will be faced in determining the outcome of the decision. Complexity also requires auditors to think about whether the task being carried out can be completed properly or not. The characteristics that exist in the auditor may reflect the quality of the audit produced by the auditor. The research method used is quantitative research methods with all members of public accountants used as population data and the use of the Likert scale as a reference in collecting questionnaire data. From the results of research that has been conducted in Medan, it can be concluded that.
\end{abstract}

Keywords: Task Complexity; Auditor Competence; Professional Skepticism; Due Professional Care.

\begin{abstract}
Abstrak
Di era modern ini, jasa seorang auditor sangat dibutuhkan oleh instansi pemerintah maupun instansi swasta karena hasil keputusan yang dibuat oleh auditor dapat mencerminkan transparansi suatu organisasi. Seorang auditor harus memiliki sikap kompetensi dan skeptisisme yang baik agar dalam menilai suatu organisasi tidak terjadi kesalahan. Sikap kompleksitas juga merupakan sikap yang harus dimiliki oleh seorang auditor dimana seorang auditor harus dapat mengetahui kesulitan atau hambatan apa yang akan dihadapi dalam menentukan hasil keputusan. Kompleksitas juga menuntut auditor untuk memikirkan apakah tugas yang dilaksanakan dapat diselesaikan dengan baik atau tidak. Karakteristik yang ada pada auditor dapat mencerminkan kualitas audit yang dihasilkan oleh auditor. Metode penelitian yang digunakan adalah metode penelitian kuantitatif dengan seluruh anggota akuntan publik digunakan sebagai data populasi dan penggunaan skala likert sebagai acuan dalam pengumpulan data kuesioner. Dari hasil penelitian yang telah dilakukan di Medan dapat disimpulkan bahwa.
\end{abstract}

Kata Kunci: Kompleksitas Tugas; Kompetensi Auditor; Skeptisme Profesional; Due Professional Care.

\section{PENDAHULUAN}

Keterampilan atau pengetahuan auditor merupakan salah satu pertimbangan yang sangat pribadi bagi seorang auditor. Standar auditing menyatakan bahwa audit harus dilakukan oleh satu atau lebih individu dengan pengalaman profesional dan kualifikasi yang sesuai sebagai auditor.

Kasus perushaan akuntan publik di Indonesia (Purwantono, Sungkoro dan Surja) terbukti melanggar UU Pasar Modal dan kode etik profesi akuntan publik dari institute akuntan publik Indonesia (IAPI). Sherly Jokom telah dihukum karena melanggar pasal 66 Aturan Jis A 14 SPAP SA 200 dan seksi 130 dari institut akuntan publik kode etik Indonesia. Kesalahan yang dilakukan oleh Sherly yaitu kesalahan penyajian (overstatement) dengan nilai mencapai Rp 613 miliar.

doi: https://doi.org/10.51544/jma.v6i1.1625

(C) 2021 Jurnal Mutiara Akuntansi . This is an open access article under the CC BY-SA license

Website: http://e-journal.sari-mutiara.ac.id/index.php/JMA/

http://e-journal.sari-mutiara.ac.id 
Dalam laporan keuangan juga tidak mengungkapkan adanya kontrak jual beli atas konstruksi tertanggal 14 Juli 2019 yang dilakukan oleh PT. Hanson Internasional. Maka dari itu Otoritas Jasa Keuangan memberikan sanksi kepada kantor akuntan publik Purwantono, Sungkoro dan Surja. Karena, dinilai tidak teliti dalam penyajian laporan keuangan PT. Hanson Internasional Tbk. Pihak OJK membekukan Surat Tanda Terdaftar (STTD) selama 1 tahun terhadap KAP tersebut. (https://www.cnbcindonesia.com/market/20190809100011-17-90855/ lagi-lagi-kap-kena-sanksi-ojk-kali-ini-partner-ey).

Berdasarkan latar belakang masalah diatas maka peneliti merumuskan masalah sebagai berikut: (1) Bagaimana hubungan kompetensi auditor dengan kualitas audit? (2) Bagaimana hubungan kompleksitas tugas dengan kualitas auditor? (3) Bagaimana hubungan skeptisme professional dengan kualitas audit? (4) Bagaimana hubungan kompetensi auditor, kompleksitas tugas, skeptisme professional terhadap kualitas audit dengan due professional care sebagai variable moderating pada kantor akuntan publik di Medan?

\section{TINJAUAN LITERATUR}

\section{Kompetensi Auditor}

Menurut Tunggal (2013:429), kompetensi adalah keahlian dan keterampilan yang dibutuhkan untuk melaksanakan tugas-tugas yang menjadi ciri pekerjaan individu.

\section{Kompleksitas Tugas}

Menurut Irwanti (2011), kompleksitas tugas adalah pemahaman individu tentang kesulitan tugas karena keterbatasan kapasitas dan memori serta kemampuan untuk mengintegrasikan tantangan yang dimliki oleh pengambil keputusan.

\section{Skeptisme Profesional}

Menurut Louwers (2011), mencatat bahwa skeptisme professional adalah kecenderungan auditor untuk tidak setuju tanpa konfirmasi dengan klaim manajemen atau untuk mempertanyakan kemampuan manajemen untuk memberikan bukti atas klaim mereka (bukti).

\section{Due Profesional Care}

Ada lima parameter, menurut Aulia (2013), yang ditentukan untuk menentukan due professional care, yaitu :

1. Kesabaran dan pengetahuan untuk pekerjaan

2. Mempunyaitekad pemenuhan tanggung jawab

3. Ahli dan waspada dalam kinerja pekerjaan

4. Adanya kemungkinan terjadi kesalahan, gangguan dan ketidakpatuhan

5.Berhati-hati terhadap ancaman yang dapat mempengaruhi objektifitas

\section{Kualitas Audit}

Menurut Rosnidah dalam Tarigan dan Susanti (2013), kualitas audit adalahmelakukan audit sesuai dengan kriteria agar lebih memungkinkan auditor untuk mngidentifikasi dan mengungkapkan jika pelanggaran terjadi pada konsumen.

\section{Pengaruh Kompetensi Auditor Terhadap Kualitas Audit}

Menurut Christiawan (2002:83), mengatakan bahwa kompetensi itu bercirikan "Mengangkat Auditor dalam audit dan akuntansi dengan pelatihan dan pengalaman yang dibutuhkan". 
Menurut Alim dkk (2007), asersi kompetensi menunjukkan bahwa semakin lama masa kerja dan keahlian auditor, semakin baik dan tinggi standar audit. Dari penjelasan diatas, maka dapat disimpulkan bahwa :

H1 : Kompetensi Auditor memiliki pengaruh Positif terhadap Kualitas Audit.

\section{Pengaruh Kompleksitas Tugas terhadap Kualitas Audit}

Ratha dan Ramantha (2015) dan Cahyono (2015) menyatakan bahwa kesulitan pekerjaan berdampak negatif terhadap efisiensi audit.

Menurut Rustiarini (2013), dalam lingkungan kerja yang dinamis, auditor bukan hanya perlu bekerja keras, tetapi juga mendapatkan keahlian dan pengalaman dalan menyelesaikan tugas auditnya. Dari penjelasan diatas, maka dapat disimpulkan bahwa:

H2 : Kompleksitas Tugas memiliki pengaruh Negative terhadap Kualitas Audit

\section{Pengaruh Skeptisme Profesional terhadap Kualitas Audit}

Standar Profesi Akuntan Publik (SPAP, 2012) menggambarkan skeptisisme professional auditor sebagai sikap yang melibatkan pikiran yang sering meragukan fakta dan menelitinya dengan kritis.

Hasil penelitian Priorina \& Ramantha $(2015 ; 12)$ menunjukkan bahwa skeptisisme, praktik audit, kompetensi dan independensi audit berpengaruh positif terhadap kualitas audit. Dari penjelasan diatas, maka dapat disimpulkan bahwa:

H3 : Skeptisme Profesional memiliki pengaruh Positif terhadap Kualitas Audit

\section{Pengaruh Due Professional Care terhadap Kualitas Audit}

Menurut Aji (2009) dalam Agustin (2013), untuk mematuhi tugas lapangan dan persyaratan pelaporan, penggunaan keahlian teknis secara presisi dan konsistensi mengutamakan kewajiban setiap teknis yang dipekerjakan dalam organisasi auditor independen.

Menurut Hardiningsih dan Oktaviani (2012), konsistensi hasil audit akan selalu dipastikan oleh setiap auditor pada tingkah pengawasan pelaksanaan audit dan setiap pertimbangan audit. Dari penjelasan diatas, maka dapat disimpulkan bahwa :

H4 : Due Professional Carememiliki pengaruh positif terhadap Kualitas Audit

\section{Kerangka Konseptual}

Kerangka konseptual dapat digambarkan dibawah ini:

Variabel Independen Variabel Dependen

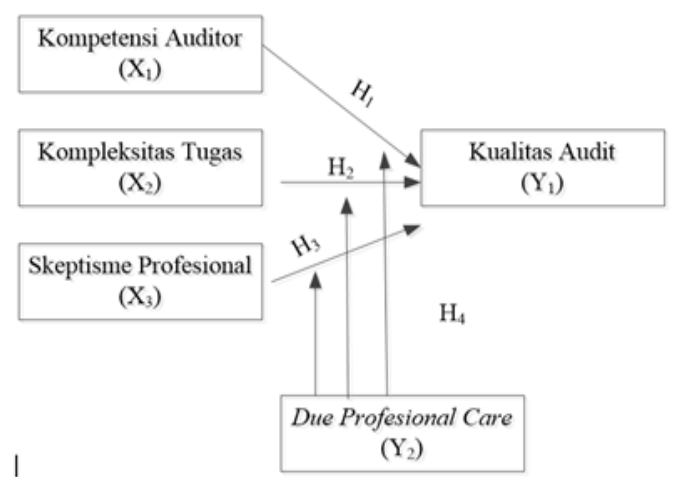

Gambar 1. Kerangka Konseptual 


\section{Hipotesis Penelitian}

Hipotesis dari penelitian diatas adalah:

H1 : Kompetensi Auditor memiliki pengaruh Positif terhadap Kualitas Audit.

H2 : Kompleksitas Tugas memiliki pengaruh Positif terhadap Kualitas Audit

H3 : Skeptisme Profesional memiliki pengaruh Positif terhadap KualitasAudit.

H4 : Kompetensi Auditor, Kompleksitas Tugas, dan Skeptisme Professional dengan Due Professional Care sebagai Variabel Moderating terhadap Kualitas Audit.

\section{METODE PENELITIAN}

Penelitian ini menggunakan metode kualitatif dengan pendekatan yang dipilih adalah deskriptif. Penelitian yang bermaksud untuk memahami fenomena tentang apa yang dialami oleh subjek penelitian misalnya perilaku, persepsi, motivasi, tindakan dan lain-lain secaraholistik dan dengan cara deskripsi dalam bentuk kata-kata dan bahasa, pada suatu konteks khusus yang alamiah dan dengan memanfaatkan berbagai metode alamiah (Moleong, 2011). Sedangkan pendekatan deskriptif dipakai untuk meneliti status kelompok manusia, suatu subjek, suatu set kondisi, suatu sistem pemikiran atau pun kelas peristiwa pada masa sekarang. Tujuan dari penelitian deskriptif ini adalah membuat deskripsi, gambaran atau lukisan secara sistematis serta hubungan antar fenomena yang diselidiki (Nazir, 2011).

Pendekatan yang digunakan dalam penelitian ini adalah metode penelitian kuantitatif. Menurut Sugiono (2016:13), pendekatan penelitian ini berdasarkan pendekatan kuantitatif. Penelitian kuantitatif merupakan penelitian dengan memperoleh data yang berbentuk kata, skema dan gambar.

\section{Teknik Pengumpulan Data}

Pengukuran tanggapan responden dilakukan dengan menggunakan skala Likert. Menurut Sugiono (2012:132) skala Likert yang dimanfaatkan untuk mengevaluasi perilaku, keyakinan dan kesan orang-orang terhadap fenomena sosial.

Populasi dan Sampel Populasi

Menurut Marissan (2012:19), populasi adalah sekumpulan topik, faktor, prinsip dan fenomena. Setiap anggota populasi dapat diteliti untuk menentukan sifat populasi yang bersangkutan. Populasi dalam penelitian ini adalah Kantor Akuntan Publik di Indonesia yaitu 30 Kantor Akuntan Publik yang terdaftar di IAPI, dengan 120 auditor yang akan menjadi sample dalampenelitian. Sampel merupakan suatu ikatan dari populasi yang dianggap merupakan perwakilan populasi penelitian. Menurut Sugiono (2017:81), sample merupakan bagian dari jumlah dan karakteristik populasi.

\section{HASIL DAN PEMBAHASAN}

Data yang digunakan dalam mengelola data adalah sebanyak 90 (sembilan puluh) set kuesioner yang diterima dari 7 (tujuh) Kantor Akuntan Publik yang terletak di kota Medan.

\section{Uji Validitas}

Menurut Ghozali (2016 : 52-53) uji validitas digunakan untuk mengetahuiakurat atautidaknya suatu kuesioner dan pertanyaan dari butir-butir pertanyaan yang telah tersaji dapat menggambarkan pengetahuan, pengalaman serta tekanan ketaatan yang dimiliki dan dialami oleh responden dalam membuat audit judgment yang baik. Dan dari olah data yang dilakukan mendapatkan data valid disetiap variabel yang diuji. 
Menurut Ghozali (2016 : 47-48) uji reabilitas sebenarnya adalah alat untuk menghitung kuesioner yang merupakan indikator dari suatu variabel atau konstruk. Pengujian Reliabilitas dilakukan untuk membantu peniliti untuk menggambarkan bahwa jawaban yang dihadirkan oleh para responden di setiap butir-butir pertanyaan yang tersaji dijawab secara konstan dan cenderung stabil. Tolak ukur uji ini menggunakan Conbanch Alpha > 0.60.

Tabel 1. Uji Reabilitas

\begin{tabular}{lc}
\hline \multicolumn{1}{c}{ Variabel } & Nilai Conbanch Alpha \\
\hline Kompetensi Auditor $\left(\mathrm{X}_{1}\right)$ & 0.591 \\
Kompleksitas Tugas $\left(\mathrm{X}_{2}\right)$ & 0.699 \\
Skeptisme Professional $\left(\mathrm{X}_{3}\right)$ & 0.699 \\
Due Professional Care $\left(\mathrm{X}_{4}\right)$ & 0.628 \\
Kualitas Audit $(\mathrm{Y})$ & 0.650
\end{tabular}

Dari data diatas dapat menggambarkan bahwa setiap jawaban per - item yang dijawab oleh responden terhadap pernyataan yang tersaji memiliki nilai konstan dan stabil.

\section{Uji Normalitas}

Menurut Ghozali (2016) uji normalitas dilakukan untuk menguji apakah variabel dependen memiliki distribusi yang teratur atau tidak normal dalam model regresi. Normalitas tersebut dapat dibuktikan dengan dua metode berupa grafik dan uji statistik. Dari hasil penggunaan pendekatan ini, dapat diperjelas jika persamaan regresi dalam analisis menghasilkan distribusi normal untuk dan variabel independen terkait dengan variabel dependen.

\section{Analisis grafik}

Pengujian Normalitas yang paling mudah untuk menggambarkan bahwanya persamaan regresi memiliki nilai residual normal. Dan hasil akhir dari analisis grafik berupa grafik Probability Plots.

\section{Grafik Probability Plots}

Tabel 2. Grafik Probability Plots

\begin{tabular}{llcc}
\hline No & \multicolumn{1}{c}{ Model } & \multicolumn{2}{c}{ Collinearity Statistics } \\
& & Tolerance & VIF \\
\hline 1 & (constant) &, 720 & \\
& kompetensi auditor &, 819 & 1,389 \\
& kompleksitas tugas &, 729 & 1,221 \\
& skeptisme professional &, 651 & 1,372 \\
& due professional care & & 1,536
\end{tabular}




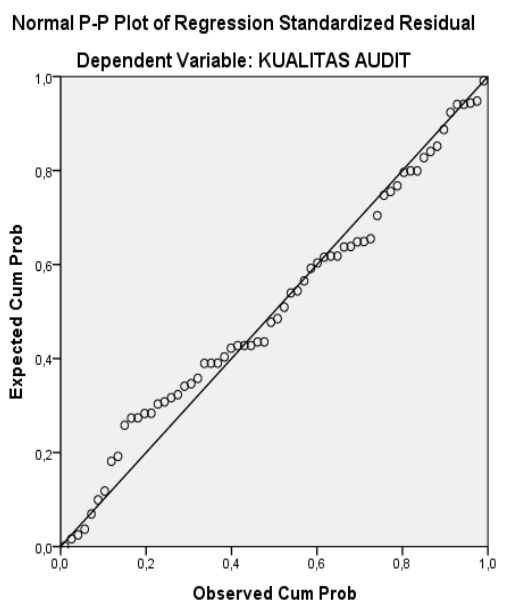

Berdasarkan hasil data output SPSS, dari hasil pengujian ini menampilkan bahwa gambar tampilan pada grafik histogram memiliki pola distribusi yang tidak melenceng ke kiri maupun ke kanan, sehinggadapat dikatakan bahwa grafik histogram tersebut berdistribusi normal. Dan pada gambar probability plots menampilkan pola bercak-bercak yang hampir seluruh pola tersebut mengikuti garis diagonal, sehingga dapat dikatakan bahwa grafik probabilty plots juga berdistribusi secara normal.

\section{Uji Statistik}

Pedoman untuk melihat bahwa hasil uji statistik bersifat normal dalam uji ini menghasilkan nilai signifikan diatas 0,05 .

Tabel 3. Uji Statistik

\begin{tabular}{|c|c|c|}
\hline One-Sample & \multicolumn{2}{|c|}{ Kolmogorov-Smirnov } \\
\hline & & $\begin{array}{l}\text { Unstandar } \\
\text { dized } \\
\text { Residual }\end{array}$ \\
\hline $\mathrm{N}$ & & 64 \\
\hline Normal & Mean & 0E-7 \\
\hline Parameters ${ }^{\mathrm{a}, \mathrm{b}}$ & $\begin{array}{l}\text { Std. } \\
\text { Deviat } \\
\text { ion }\end{array}$ & $\begin{array}{l}2,9980867 \\
8\end{array}$ \\
\hline $\begin{array}{l}\text { Most } \\
\text { Extreme }\end{array}$ & $\begin{array}{l}\text { Absol } \\
\text { ute }\end{array}$ &, 111 \\
\hline \multirow[t]{2}{*}{ Differences } & $\begin{array}{l}\text { Positiv } \\
\mathrm{e}\end{array}$ &, 074 \\
\hline & $\begin{array}{l}\text { Negati } \\
\text { ve }\end{array}$ &,- 111 \\
\hline \multicolumn{2}{|c|}{ Kolmogorov-Smirnov Z } &, 885 \\
\hline \multicolumn{2}{|c|}{ Asymp. Sig. (2-tailed) } & ,414 \\
\hline
\end{tabular}

Berdasarkan hasil output yang terdapat pada tabel diatas memiliki nilai yang signifikan dengan nilai 0,414 maka memenuhi uji statistik yang diharapkan dan berdistribusi normal. 


\section{Uji Multikolinieritas}

Tujuan dari uji multikolinieritas Ghozali (2016) adalah untuk mengetahui apakah dalam model regresi ditemukan adanya korelasi antara variabel bebas atau variabel terikat. Uji multikolinieritas dilakukan untuk memverifikasikan bahwa tidak ada hubungan antara setiap variabel independen. Model regresi yang baik sebaiknya tidak dikorelasikan dengan variabel independen.

\section{Uji Heteroskedatisitas}

Menurut Ghozali (2016 : 139) uji heteroskedatisitas bertujuan untuk menguji apakah dalam model regresi terjadi ketidaksamaan varian dari residual 1 pengamat ke pengamat lainnya. Untuk memahami hasil uji heteroskedatisitas dapat dilihat melalui bentuk grafik sketterplot dan uji glejser. Adapun uji heteroskedastisitas dilakukan untuk melihat dan menilai varian yang terdapat dalam regresi linier yang sedang di observasi apakah memiliki kesamaan dengan variabel yang lain (homoskedatisitas).

Uji scatterplots

Tabel 4. Uji Scatterplots

\begin{tabular}{|c|c|c|c|c|c|}
\hline Model & $\mathrm{R}$ & R Square & $\begin{array}{l}\text { Adjusted } \\
\text { Square }\end{array}$ & $\mathrm{R}$ & $\begin{array}{l}\text { Std. Error of the } \\
\text { Estimate }\end{array}$ \\
\hline 1 &, $593^{\mathrm{a}}$ & ,352 & ,308 & & 3,098 \\
\hline
\end{tabular}

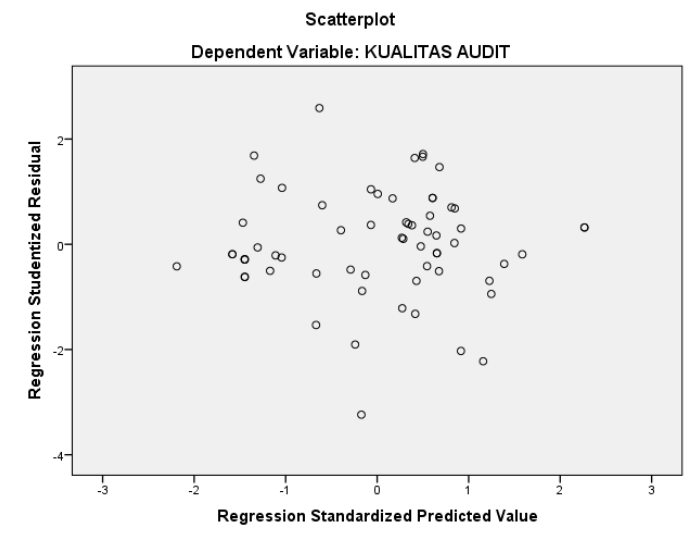

Hasil output SPSS pada grafik sketterplot tampak bahwa setiap pola bercak-bercak tidak membentuk suatu objek secara spesifik melainkan meyebaar diaatas origin pada sumbu Y secara acak, sehingga dapat disimpulkan bahwa grafik sketterplot bersifat homokedatisitas (tidak memiliki gejala heterokedatisitas.

Uji Park

Tabel 4. Uji Park

Model Unstandardized Coefficients

B

Std. Error

(Constant)

8,060

7,212 


$\begin{array}{lcc}\text { kompetensi auditor } & -, 001 & , 103 \\ \text { kompleksitas tugas } & , 301 & , 138 \\ \text { skeptisme professional } & , 370 & , 126 \\ \text { due professional care } & , 150 & , 131\end{array}$

\section{Hasil Analisis Data Penelitian}

Penggunaan Analisis Linear Berganda merupakan serangkaian uji untuk meninjau seberapa besar pengaruh variabel bebas memiliki kontribusi sangat berpengaruh kepada variabel terikat. Dengan rumus :

$\mathrm{Y}=\mathrm{a} 0+\mathrm{b} 1 \mathrm{X} 1+\mathrm{b} 2 \mathrm{X} 2+\mathrm{b} 3 \mathrm{X} 3+\mathrm{e}$

a. Koefisien determinasi

Model Summaryb

\section{Pengujian Hipotesis Secara Simultan (Uji F)}

Uji F (Uji Simultan) ini dapat membantu peneli untuk mengetahui bahwa dalam variabel bebas (Kompetensi Auditor, Kompleksitas Tugas dan Skeptisme Professional) secara keseluruhan memberikan pengaruh positif terhadap variabel terikat (Kualitas Audit), dengan pedoman bahwa nilai $\mathrm{F}$ hitung $>\mathrm{F}$ tabel dan level signifikan $<0,05$.

Tabel 5. ANOVA ${ }^{\mathrm{a}}$

\begin{tabular}{|c|c|c|c|}
\hline Model & & $\mathrm{F}$ & Sig. \\
\hline \multirow[t]{4}{*}{1} & Regressi & 8,009 &, $000^{\mathrm{b}}$ \\
\hline & on & & \\
\hline & Residual & & \\
\hline & Total & & \\
\hline
\end{tabular}

Pengujian Hipotesis Secara Parsial (Uji t)

Pengujian hipotesis parsial memiliki peranan untuk meninjau setiap variabel bebas (Kompetensi Auditor, Kompleksitas Tugas dan Skeptisme Professional) mempunyai kontribusi berpengaruh kepada variabel terikat (Kualitas Audit).

\begin{tabular}{lll}
\multicolumn{3}{c}{ Tabel 6. Uji t } \\
\hline Model & $\mathrm{t}$ & Sig. \\
\hline (Constant) & 1,118 &, 268 \\
KOMPETENSI &,- 007 &, 994 \\
AUDITOR & & \\
KOMPLEKSITAS & 2,186 &, 033 \\
$\begin{array}{l}\text { TUGAS } \\
\text { SKEPTISME }\end{array}$ & 2,943 &, 005 \\
AUDITOR & &
\end{tabular}


DUE $\quad 1,150 \quad 255$

PROFESSIONAL

CARE

\section{Pengaruh Kompetensi Auditor terhadap Kualitas Audit}

Hasil penelitian ini menunjukkan bahwa kompetensi auditor beperngaruh negatif terhadap kualitas audit pada Kantor Akuntan Publik di Medan dengan nilai thitung $<$ ttabel atau $0,007<2,00100$ dan nilai signifikan 0,994 > 0,05. Temuan penelitian ini sejalan dengan hasil penelitian yang dilakukan oleh Nur (2011) dimana hasil penelitiannya untuk kepentinganauditor tidak berdampak langsung terhadap kualitas audit. Demikian pula penelitian yang dilakukan oleh Dewi dan Budiarta (2015) mencatat bahwa kompetensi informasi tidak beerpengaruh besar terhadap kualitas audit. Konsekuensinya, dari temuan analisis ini dapat dijelaskan bahwa semakin tinggi tingkat pengalaman yang dimiliki auditor, tidak menjamin bahwa standar audit akan semakin tinggi. Semakin tinggi integritas auditor, semakin lihai melakukan kecurangan saat melakukan audit.

\section{Pengaruh Kompleksitas Tugas terhadap Kualitas Audit}

Hasil penelitian menunjukkan bahwa kompleksitas tugas berpengaruh positif dan penting terhadap kualitas audit pada Kantor Akuntan Publik di Medan dengan nilai thitung $>$ ttabel atau $2,186>2,00100$ dan nilai signifikan $0,033<0,05$. Temuan penelitian ini sejalan dengan analisis Pahrun (2014) dimana kompleksitas berpengaruh positif terhadap kualitas audit. Hal ini menandakan bahwa semakin besar tingkat kesulitas suatu pekerjaan, semakin tinggi pula keluarannya dan sebaliknya. Namun temuan penelitian ini tidak sejalan dengan penelitian yang dilakukan oleh Yudah (2017) dimana kompeksitas audit berpengaruh negatif terhadap kualitas audit, hal ini menunjukkan bahwa semakin tinggi kompleksitas tugas maka akan semakin rendah kualitasnya dari audit.

\section{Pengaruh Skeptisme Professional terhadap Kualitas Audit}

Hasil penelitian menunjukkan bahwa skeptisme professional berpengaruh positif dan penting terhadap kualitas audit pada Kantor Akuntan Publik di Medan dengan nilai thitung> ttabel atau 2,943 > 2,00100 dan nilai signifikan 0,005 $<0,05$. Temuan penelitian ini sejalan dengan penelitian yang dilakukan oleh Sudrajat (2015) menunjukkan bahwa skeptisme professional berpengaruh besar terhadap kualitas audit.Skeptisisme professional auditor diperlukan agar penugasan audit selalu menantang dan menilai secara kritis bukti audit yang diperoleh. Dengan menerapkan pola pikir auditor yang kompeten skeptis, maka kualitas kinerja audit dapat ditingkatkan. Dapat juga disimpulkan bahwa skeptisme auditor yang kompeten memiliki pengaruh substansional terhadap kualitas audit.

\section{Pengaruh Due Professional Care terhadap Kualitas Audit}

Hasil penelitian menunjukkan bahwa due professional care berpengaruh positif dan penting terhadap kualitas audit pada Kantor Akuntan Publik di Medan dengan nilai thitung> ttabel atau 1,150> 2,00100 dan nilai signifikan 0,255>0,05. Temuan penelitian ini sejalan dengan penelitian yang dilakukan oleh Febriyanti (2014) yang dalam penelitiannya menyatakan bahwa due professional care berpengaruh terhadap kualitas audit. Sesuai dengan pengertian pertimbangan due professional care yang tepat, yaitu konsistensi profesional, dalam pelaksanaan 
tugasnya, auditor juga harus selalu memperhatika berbagai potensi risiko yang dapat ditimbulkan dari temuan auditnya, dengan memperhatikan berbagai kemungkinan yang ada. Mungkin muncul dan solusi alternatif. Semakin tinggi tingkat akurasi dan kemampuan auditor yang digunakan untuk menjalankan tugasnya, semakin kecil kemungkinan terjadinya kesalahan, sehingga konsistensi audit akan semakin meningkat.

\section{KESIMPULAN}

Berdasarkan hasil penelitian yang telah dilakukan pada Kantor Akuntan Publik yang berada di Kota Medan, maka dapat disimpulkan bahwa :

1. Kompetensi Auditor berpengaruh negatif terhadap Kualitas Audit pada Kantor Akuntan Publik di Medan

2. Kompleksitas Tugas berpengaruh positif dan signifikan terhadap Kualitas Audit pada Kantor Akuntan Publik di Medan

3. Skeptisme Professional berpengaruh positif dan signifikan terhadap Kualitas Audit pada Kantor Akuntan Publik di Medan

4. Due Professional Care berpengaruh positf dan signifikan terhadap Kualitas Audit pada Kantor Akuntan Publik di Medan

Dari hasil uji koefisien determinasi menunjukkan 59\% variasi variabel Kualitas Audit (Y) dapat dijelaskan oleh variabel Kompetensi Auditor (X1), Kompleksitas Tugas (X2) dan Skeptisme Professional (X3), sedangkan 41\% dijelaskan oleh variabel lain yang tidak digunakan pada penelitian ini

Saran-saran yang berguna diantaranya :

1. Bagi para peneliti yang selanjutnya diharapkan untuk terus melakukan penelitian dengan menambahkan variabel baru untuk mengutur seberapa besar pengaruh yang ditimbukan terhadap Kualitas Audit pada Kantor Akuntan Publik di Kota Medan.

2. Bagi pihak universitas, semoga penelitian ini dapat menjadi kontribusi bagi pihak lainnya untuk melanjutkan penelitian selanjutnya

3. Peneliti menyadari keterbatasan dalam melaksanakan penelitian karena pembagian koesioner dilakukan pada saat pandemi Covid-19 sehingga memiliki sample dalam penelitian ini terbatas. Untuk itu diharapkan kepada peneliti selanjutnya untuk dapat melakukan penelitian secara optimal

\section{DAFTAR PUSTAKA}

"Pengaruh Kompetensi Auditor Terhadap Kualitas Audit dengan Kecerdasan Spiritual sebagai Variabel Moderating”. http://repository.unpas.ac.id/12258/

"Pengaruh Kompleksitas Tugas, Tekanan Ketaatan, Tingkat Senioritas Auditor, dan Hubungan dengan Klien terhadap Audit Judgement". https://media.neliti.com/media/publications/ 33409-ID-pengaruh-kompleksitas-tugas-tekanan-ketaatan-tingkat-senioritas-auditorkeahlian.pdf

"Pengaruh Skeptisme Professional, Independensi, Kompetensi, Pelatihan Auditor, dan Resiko Audit terhadap Tanggung Jawab Auditor dalam Mendeteksi kecurangan". http://journal.unika.ac.id/index.php/jab/article/viewFile/1350/834

"Pengaruh Pengalaman, Independensi, Dan Due Profesional Care Auditor Terhadap Kualitas Audit Laporan Keuangan Pemerintah".http://repository.uinjkt.ac.id/dspace/bitstream/ 123456789/23844/1/MUHAMMAD\%20YUSUF\%20AULIA.pdf 
"Pengaruh Kompetensi, Etika, dan Fee Audit Terhadap Kualitas Audit". http://ejournal.ukrida.ac.id/ojs/index.php/Akun/article/view/819/798

"Kompetensi dan Independensi Akuntan Publik : Refleksi Hasil Penelitian Empiris". http://jurnalakuntansi.petra.ac.id/index.php/aku/article/view/15692

"Pengaruh Kompetensi dan Independensi terhadap Kualitas Audit dengan Etika Auditor sebagai Variabel Moderasi”. http://eprints.undip.ac.id/35828/1/jurnal_skripsi_NORMA.pdf

"Pengaruh Due Professional Care, Akuntabilitas, Kompleksitas Audit, dan Time Budget Pressure Terhadap Kualitas Audit”. https://ojs.unud.ac.id/index.php/Akuntansi/article/view/13396

"Pengaruh Kompetensi, Pengalaman kerja, Independensi, Akuntabilitas, Intergritas, dan Obyektivitas

Kualitas

Audit”.http://eprints.ums.ac.id/43288/4/NASKAH\%20PUBLIKASI.pdf

"Etika Auditor Memoderasi Pengaruh Pengalaman Auditor, Kompetensi dan Due Proffesional Care pada Kualitas Audit”.https://ojs.unud.ac.id/index.php/Akuntansi/article/download/29404/19367

"Pengaruh Pengalaman Auditor, Tekanan Ketaatan dan Kompleksitas Tugas Terhadap Audit Judgement".http://repository.unpas.ac.id/15474/

"Pengaruh Independensi, Pengalaman, Due professional Care, Akuntanbilitas terhadap Kualitas Audit".http://eprints.ums.ac.id/39007/23/NASKAH\%20PUBLIKASI..pdf

"Pengaruh Kompetensi dan Independensi Auditor Terhadap Kualitas Audit ".https://repository.maranatha.edu/2066/

“Analisis Uji Asumsi Klasik”. https://bbs.binus.ac.id/management/2019/12/analisis-uji-asumsiklasik/

Ghozali, Imam. 2016. Aplikasi Analisis Multivariete Dengan Program IBM SPSS 23 (Edisi 8). Cetakan ke VIII. Semarang : Badan Penerbit Universitas Diponegoro. 